Helgoländer wiss. Meeresunters. 20, 685-690 (1970)

\title{
The trichterkreisel, an in situ device for cultivating marine animals in tidal currents
}

\author{
P. JATZKe \\ Biologische Anstalt Helgoland (Meeresstation); Helgoland, Germany (FRG)
}

\begin{abstract}
KURZFASSUNG: Der Trichterkreisel, ein In-situ-Gerät zur Kultur mariner Tiere in Gezeitenströmen. Zur Hälterung und Aufzucht von Larven und Jungtieren des Hummers Homarus gammarus wurde eine Vorrichtung geschaffen, die den Versuchstieren weitgehend natürliche Lebensbedingungen bietet. Diese Vorrichtung, der sogenannte "Trichterkreisel“, ist ein aufrechtstehender Plexiglaszylinder, der in beliebigen Tiefen auf dem Meeresgrund verankert werden kann. Der Tidenstrom gelangt durch zwei trichterförmige Offnungen in den Zylinder. Mittels einer besonderen Düsenanordnung wird das einströmende Wasser so abgelenkt, daß der Wasserkörper im Trichterkreisel um seine Vertikalachse rotiert. Am oberen Ende des Kreisels kann das Wasser entweichen. Da die obere Ơffnung um ein Vielfaches größer ist als die beiden Einlaßdüsen, bleibt die Intensität der aufwärtsgerichteten Wasserströmung gering. Ein- und Ausstromöffnungen sind mit gazebespannten auswechselbaren Rähmchen versehen. Die Maximalgrößße der eingeströmten Planktonorganismen kann durch die gewählte Gazegröße verändert werden. Schwimmende Hummerlarven gerieten infolge der Wasserrotation nur selten in Wandkontakt. Das einströmende Plankton dient den Hummerlarven als Nahrung. Im Trichterkreisel entwickeln sich auch Larven anderer Organismen (mitunter bis zu adulten Stadien), die von den Junghummern verzehrt wurden. Ein seit 17 Monaten laufendes Experiment am Boden der Nordsee zeigt, daß sich der im Trichterkreisel befindende Junghummer ohne zusätzliche Fütterung ebenso gut entwickelt wie Vergleichstiere, die im Laboratorium unter ähnlichen Bedingungen lebten und regelmäßig gefüttert werden. Es ist beabsichtigt, große Trichterkreisel zu bauen, um damit die Voraussetzung für eine Massenzucht von Helgoländer Hummern zu schaffen.
\end{abstract}

\section{INTRODUCTION}

In recent years, cultivation of marine organisms has attained a new dimension. In addition to ship cruises and experiments under laboratory conditions, the marine biologist is beginning to conduct research in the sea itself. At the Biologische Anstalt Helgoland, scientific diving has been carried out since 1965. In order to cultivate marine organisms in situ it is essential to develop new techniques which facilitate long term maintenance and cultivation of defined test organisms. I have attempted to develop special under-water cages, in which marine animals can live and thrive under practically natural conditions. 


\section{RESULTS}

On Helgoland we have developed an in situ cultivation unit - called "trichterkreisel" which, from the outset, produced good results. On August 27th 1968, a trichterkreisel was placed on the sea floor between Helgoland and the Düne at a water depth of $8 \mathrm{~m}$ and marked by a surface buoy. A 4 months' old lobster Homarus gammarus, raised from the egg under defined laboratory conditions, was placed in the trichterkreisel. During the first 8 weeks the lobster was fed every 8 days with one living specimen of Galathea squamifera which had the same length as the lobster.

At the beginning of October 1968, heavy storms tore off the marker buoy. Due to further storms and bad under-water visibility the trichterkreisel station could not be located and hence the experiment was discontinued. However, in the following spring the trichterkreisel was found again. The lobster was still alive and had grown just as well as lobsters of the same brood kept under laboratory conditions at comparable temperature.

Since the lobster in the trichterkreisel had, in contrast to the laboratory-raised lobster, not been fed throughout the 6 months' period, the water current in the trichterkreisel must have provided sufficient food. The lobster in the trichterkreisel was heavily pigmented and in company of many other organisms, which had grown too big to leave the trichterkreisel. From now on, 17 months after the beginning of the experiment, the lobster was never again fed artificially. Nevertheless, it continued to grow at rates identical to those of regularly fed lobster from the same brood kept under laboratory conditions.

In further under-water experiments the trichterkreisel has proven a useful tool for in situ cultivation of larvae and adults of Homarus gammarus and for larvae and adults of other plankton organisms (larvae of Eupagurus bernhardus and Galathea squamifera; adults of Beroe spec. and Pleurobrachia pileus). In general the larvae tend to swim against the rotating water current. If the speed of the current exceeds their own locomotion rates the larvae are carried around with the rotating water; if the speed becomes smaller, the larvae swim against the rotating water without frequent contact with the wall of the cylinder. Big surface waves, create in the trichterkreisel a fast, vertical water movement and the larvae may be pressed against the gauze of the water outlet or against the bottom. In either case they suffer or even die. To avoid such detrimental effects an antiturbulence cover was added (above the outlet) which dampens transmission of the vertical water movement.

\section{Description of the trichterkreisel}

The trichterkreisel (Fig. 1) consists of a cylinder $\left(c_{1}\right)$ of transparent plexiglass, also known as perspex, of $50 \mathrm{~cm}$ length and $47 \mathrm{~cm}$ diameter. The lower opening of the cylinder is covered with a perspex baseplate (bp). The upper opening consists of a disc of plexiglass, containing a hole $30 \mathrm{~cm}$ in diameter, onto which a cylinder $\left(\mathrm{c}_{2}\right)$ is screwed, $10 \mathrm{~cm}$ long and $30 \mathrm{~cm}$ in diameter. The outlet opening is covered by gauze $\left(g_{1}\right)$. An antiturbulence cover (ant) is attached $5 \mathrm{~cm}$ above the top disc. Two 
funnel-shaped entrances $\left(f_{1}, f_{2}\right)$ are secured to jet openings $\left(j_{1}, j_{2}\right) 4 \mathrm{~cm}$ in diameter, in the wall of the cylinder $\left(c_{1}\right)$, located opposite to each other. All openings are covered by gauze-frames $\left(\mathrm{g}_{1}, \mathrm{~g}_{2}, \mathrm{~g}_{3}\right)$. Two directional current plates $(\mathrm{dcp}), 8 \mathrm{~cm}$ in length, are attached diagonally at the openings $j_{1}$ and $j_{2}$. The trichterkreisel is fastened
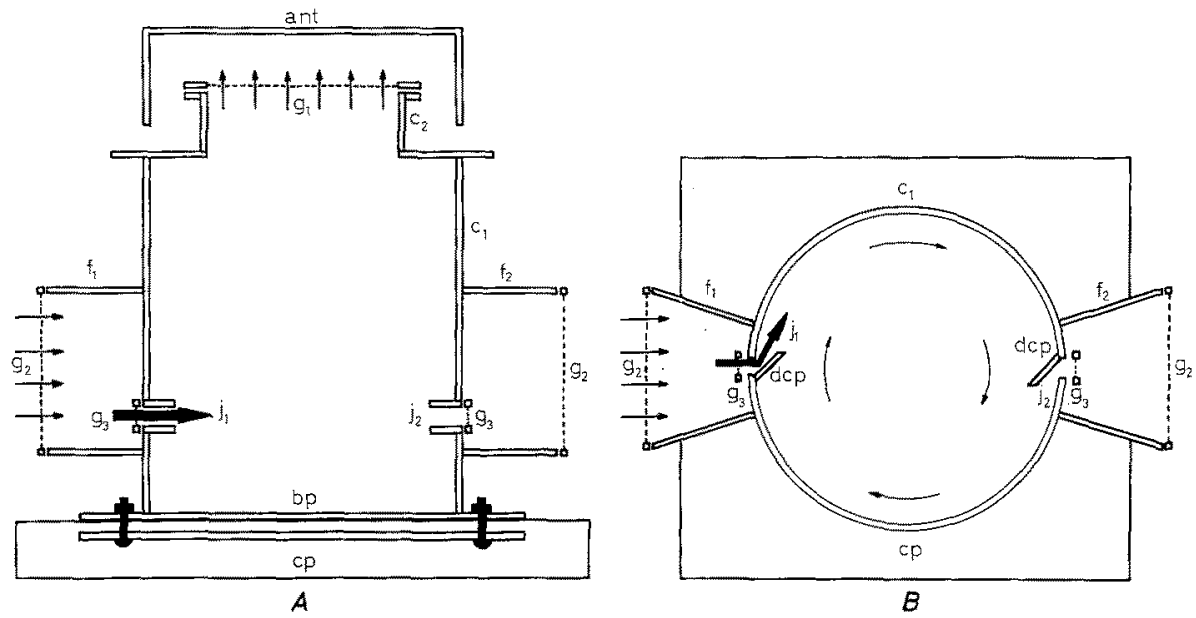

Fig. 1: Trichterkreisel. (A) Vertical section, (B) cross section; ant antiturbulence cover, $b p$ baseplate, $c_{1}, c_{2}$ cylinder, $c p$ concrete plate, $d c p$ diagonal current plate, $f_{1}, f_{2}$ fumnels, $g_{1}, g_{2}, g_{3}$ gauze covered frames, $j_{1}, j_{2}$ inlet-jets

with its bottom plate onto a heavy concrete plate (cp) by screws. Arrows in Figure 1 indicate water movement in the trichterkreisel, when exposed to tidal currents. Entrance of tidal currents is from left or right and alternates with tidal conditions.

The speed of water rotation varies with the tide; during low or high water, current velocity is low and rotation slows; with increasing tidal current speed rotation increases again. In addition, rotation speed within the trichterkreisel can be regulated by the size of the diameters of the inlet-jets $j_{1}$ and $j_{2}$ and that of the funnels $f_{1}$ and $f_{2}$.

\section{Functioning of the trichterkreisel}

The trichterkreisel is placed under water in such a way that the funnel-shaped openings face the tidal currents (Figs. 2, 3). During ebb flow the water current enters the trichterkreisel through one of the funnel-shaped openings. A directional current plate directs the water flow into circular motion, so that the whole water body in the cylinder begins to rotate around its vertical axis. The same effect is achieved during flood flow. Water of the tidal current which enters either inlet-jet escapes through the gauze covered outlet opening at the top of the trichterkreisel. Since the outlet opening has a larger diameter than the inlet-jets, the upwardly directed water rotation is weak. 
When the trichterkreisel is placed in water depths less than about $20 \mathrm{~m}$, it is necessary to protect it by an antiturbulence cover; otherwise wave motion could affect the water body in the cylinder and may lead to a temporary breakdown of its vertical rotation or to damage of the organisms cultivated.

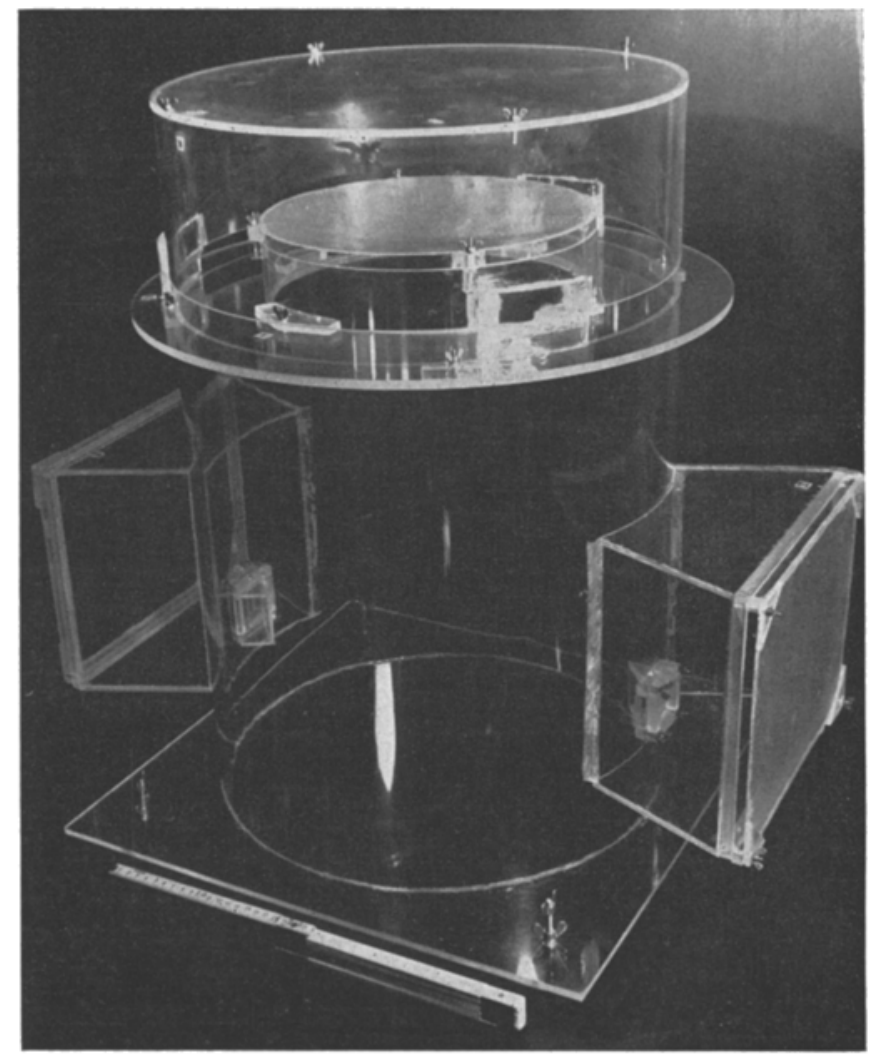

Fig. 2: Trichterkreisel, ready to be positioned on the sea-bed

While the gauze size of the frames is selected in such a way that the test animals cannot escape, smaller plankton may enter. In our experiments, larvae of many different animals entered with the inflowing water; some of them developed well within the trichterkreisel, a few even to adult stages. After 3 weeks, the trichterkreisel contained coelenterates (Tubularia larynx), polychaetes (Pomatoceros triqueter, Nereis pelagica), crustaceans (Balanus crenatus, Galathea squamifera); however, Homarus gammarus remained the dominant animal, feeding on the other members of the microbiotope. After nearly 2 summer months, the gauze became almost impermeable to the tidal current owing to the build up of sediment and sessile organisms (especially Tubularia larynx, Mytilus edulis, and Polydora ciliata). Hence the gauze frames must be changed periodically. When the cultivated lobsters grow larger, a gauze aperture of larger size is chosen, and still larger organisms can now enter the trichterkreisel. 
Since lobsters are cannibals and require a certain territory for their own it is necessary to provide sufficient niches and holes for metamorphosing larvae on the bottom of the kreisel. Adult lobsters must be kept in different kreisels or in kreisels with sections. A trichterkreisel containing two 2 year old lobsters was placed beside the underwater laboratory "Helgoland" in a water depth of $23 \mathrm{~m}$. Although more

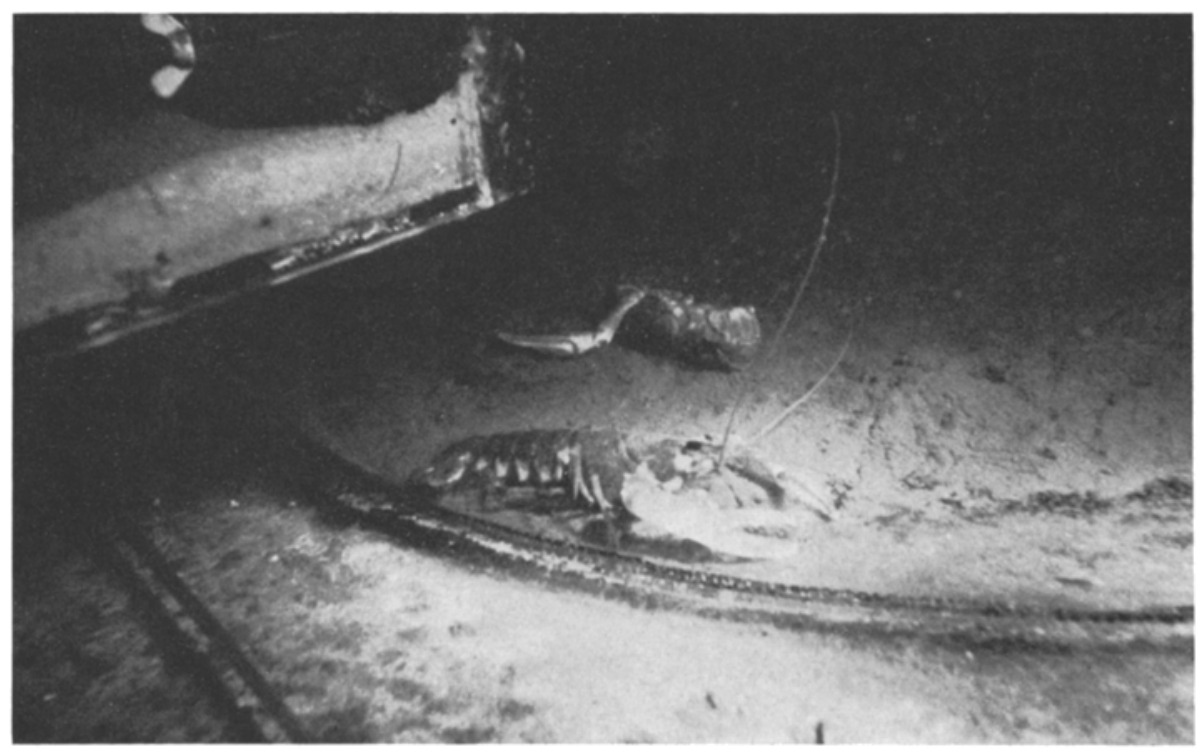

Fig. 3: Trichterkreisel in action during experiments conducted by aquanauts from the underwater laboratory "Helgoland" in July-August 1969. Water depth: $23 \mathrm{~m}$; visibility: $4 \mathrm{~m}$

than sufficient food was provided (meat from the flatfish Limanda limanda and the crab Portunus bolsatus), the two lobsters attacked each other and within $6 \mathrm{~h}$ one lobster was killed.

Since the trichterkreisel has proved successful for in situ cultivation of lobster larvae, adult lobsters, other crustaceans, molluscs and coelenterates we plan to develop a prototype on a mud larger scale. Present plans call for a trichterkreisel of about 10-20 $\mathrm{m}$ diameter and a total height of $2-3 \mathrm{~m}$. We hope to use it for raising lobsters and fishes (e. g., Psetta maxima, Solea solea, Pleuronectes platessa).

\section{SUMMARY}

1. Cultivation of marine animals in the open sea requires development of special equipment. The trichterkreisel facilitates maintenance and cultivation of several marine animals (Homarus gammarus, Galatbea squamifera, Mytilus edulis, and others). It represents, in essence, an upright standing cylinder, into which tidal currents enter at the bottom, rotate and slowly leave at the top through a gauze cover. 
2. Small plankton organisms enter the trichterkreisel with the water flow, passing through gauze-covered frames and thus provide food for the animals cultivated. Some of the plankton forms metamorphose and grow in the device until devoured.

3. During a 17 months' experiment a young lobster Homarus gammarus grew at a normal rate in a trichterkreisel without any artificial feeding. A large in situ trichterkreisel for cultivating masses of lobster larvae is planned for the near future.

Author's address: P. JATZKE

Biologische Anstalt Helgoland

Meeresstation

2192 Helgoland

Germany (FRG) 